Indonesian Journal of Biotechnology, June, 2015

Vol. 20, No. 1, pp.11-18

\title{
Marker Assisted Selection for Bacterial Leaf Blight Rice Mutant Lines Resistant
}

\author{
Aryanti $^{1}$, Almaida $^{1}$, Rika Heryani $^{1}$ and Nana Supriatna ${ }^{1}$ \\ ${ }^{1}$ Centre for Isotopes and Radiation Application, BATAN, Indonesia
}

\begin{abstract}
Induction of mutation using gamma rays for improving of Mira-1 rice variety has been conducted. Rice mutant lines M2 generation have been obtained from mutation by the doses of 25, 50, 75, 100, 150 and $200 \mathrm{~Gy}$ of gamma rays. Selection of mutant lines tolerant to the disease was only observed in the field neither genetically. Marker assisted selection is a tool to obtain a new rice variety tolerant to the disease of bacterial leaf blight (BLB) genetically. Xanthomonas oryzae pv.oryzae (Xa) was the pathogen of BLB, and the identification of rice mutant lines which were containing of Xa5, Xa13 and Xa21 genes have been done using Polymerase Chain Reaction ( PCR ) method. The result showed that one mutant line, and four mutant lines from mutation by the doses of 25 Gy and 150 Gy were containing Xa5, Xa13 and Xa21 genes the same as that of Code rice variety as positive control, and none in Kencana Bali rice variety as negative control. Mira-1 rice variety as the parent plant was only contains Xa5 and Xa21 genes. The doses of $50 \mathrm{~Gy}$ and $100 \mathrm{~Gy}$ were very affective on removing of all bands for identification of those genes. The purpose of this research was to obtain the mutant lines which were contain of those Xa genes as indicator for resistant to BLB disease genetically.
\end{abstract}

Keywords: bacterial leaf blight (BLB), marker assisted selection, $\mathrm{PCR}, \mathrm{X} a$, rice mutant lines

\section{Introduction}

Indonesia is the $5^{\text {th }}$ biggest country in the world, for populations of 250 million, the country needs 35.5 million ton rice per year. According to Central Bureau of Statistics, in the middle of 2013, Indonesia rice production was only 22.897 million ton, this figure is far below the Agriculture Ministry's target. The problem is not limited due to an imbalance of supply and demand, and the changing of agriculture area to non agriculture use, but also losses of grain yield by infection of diseases, pest and other causes.

Bacterial leaf blight (BLB) caused by Xanthomonas oryzae pv.oryzae $(\mathrm{X} a)$ is one of the major biotic destructive diseases throughout the world (Zhang and Wang 2013). The disease is known to occur in

* Corresponding Author:

Aryanti

Centre for Isotopes and Radiation Application,

BATAN. Email: aryanti@batan.go.id epidemic proportions in many parts of the world including Indonesia. Indonesia is a tropical region with high humidity which causes the disease develop easily. The peak of BLB disease attack to rice occurred in 2006 where 74,243 ha of rice damaged (Suryadi et al., 2012). Crop loss assessment studies have revealed that this disease reduces grain yield to varying levels, depending on the stage of the crop. The degree of cultivar susceptibility to great extent, the conduciveness of the environment in which it occurs. Reported by Herlina and Silitonga (2011), showed that $30-40 \%$ decrease of rice production by this pathogen.

To develop a new rice variety tolerant against the disease, crossing between two parents which contain resistance to BLB have been conducted by some researchers, i.e, the presence of disease resistance genes in rice, has been developed by crossbreeding (Baehaki, 2012). Another tool to develop of rice tolerant to pathogen was by gamma 
rays. Gamma rays is physical mutagen which produce of free radicals from radiolysis of water, it will break of linkage genes and produce varies of plants genetically. The rice mutant traits were low amylose content, tillering ability, dwarf plants, and resistance to the pathogen.

Tanaka et al. ( 2010 ) mentioned that ionizing radiation could generate many kind of phenotypes, because it induces DNA damage relatively randomly, and therefore, induces a series of mutation. National Nuclear Energy Agency (NNEA/BATAN) has 20 rice varieties released since 1982, and the varieties should be resistant to diseases. All of new rice varieties were mutated by gamma rays. One of BATAN rice variety is Mira- 1 which was released in 2006, this variety has less tasty when cooked, moderately resistant to Brown Plant Hopper (BPH) and Bacterial Leaf Blight (BLB) disease. For this reason, it is necessary to improve the Mira-1 plant traits. One of the steps to get a new rice variety is a selection. Selection of mutant lines based on genetic information is very valuable beside observation in the field. Marker assisted selection is a tool to find the mutant lines contains Xhantomonas oryzae ( $\mathrm{Xa}$ ) genes as an indicator of resistance to BLB.

The development of molecular markers diagnostic for the selection of resistant genes is the goal of many rice breeding programs. Several of the major resistance genes to the bacterial leaf blight (BLB) pathogen, Xanthomonas oryzae pv.oryzae have been tagged with restriction fragment length polymorphism (RFLP) or Simple Sequence Repeat (SSR) markers (Lukman et al., 2013, Singh et al., 2015). However, information of studies on molecular marker to differentiate between mutants and their parent plant are very limited.

The purpose of this research is to obtain rice mutant lines containing the Xanthomonas oryzae (Xa5, Xa13 and Xa21) genes as an indication of BLB resistance.

\section{Material and Methods}

Plant Materials. M2 plant mutant lines from Citayam-Indonesia rice field was used for this experiment. Mutant lines obtained by irradiation of 200 rice plants at stage of 10 days before anthesis. Gamma rays doses used were 25, 50, 75, 100, 150 and 200 Gy. The selected numbers of mutant lines were analyzed based on the agronomic trait in the field and seeds number per panicle. A number of individual plants of 30 mutant lines for each dose were used for the analysis.

Plant genomic DNA extraction. To obtain of DNA mutant lines, leaves were extracted by mini prepraparation using CTAB method, and DNA diluted in $50 \mu \mathrm{l}$ of 1xTAE.

Polymerase Chain Reaction (PCR). PCR reactions were performed of $25 \mathrm{ul}$ reaction volume consisting, $2.5 \mathrm{ul} 10 \mathrm{x}$ buffer, $1.5 \mathrm{ul}$ of $25 \mathrm{mM} \mathrm{MgCl2}, 5$ ul 5Q, 1UL of 10 mM dNTP mix, 0.75 ul of primer $R, 0.75$ ul of primer F, $0.25 \mathrm{ul}$ of Taq polymerase enzyme $5 \mathrm{U} / \mathrm{ul}, 8.25 \mathrm{ul}$ of DEPC and $5 \mathrm{ul}$ of rice DNA. PCR reaction was carried out with the conditions of (i) denaturation of 5 min at $94^{\circ} \mathrm{C}$, ( ii ) denaturation during 1 minute at $94^{\circ} \mathrm{C}$, annealed 1 minute at the temperature of $55^{\circ} \mathrm{C}$, extension $72^{\circ} \mathrm{C}$ for 2 minutes, extended extension $72{ }^{\circ} \mathrm{C}$ for 7 minutes. The number of cycles were 40 cycles, PCR products were

Table 1. List of bacterial leaf blight resistance genes and sequence of primers

\begin{tabular}{cccl}
\hline No & Gene & Chromosome locus & \multicolumn{1}{c}{ Primer Sequence } \\
\hline 1 & $X a 5$ & 5 & F:AGACGCGGAAGGGTGGTTCCCGGA \\
& & & R:AGACGCGGTAATCGAAGATGAAA \\
2 & $X a 13$ & 8 & F:GGCCATGGCTCAGTGTTTAT \\
& & \multirow{2}{*}{11} & R:GAGCTCCAGCTCTCCAAATG \\
3 & $X a 21$ & & F:TCCAACATGGCAAGAGAGAG \\
& & & R:GGTGGCATTCGATTCCAG \\
\hline
\end{tabular}


separated on $1.5 \%$ agarose by using of 100 bp DNA leader. The bacterial leaf blight resistance genes and sequence of primers is shown in Table 1.

\section{Result and Discussion}

It is expected that gamma - rays mutagenesis could cause many variations in the disease responses of rice plants. Mutations are changes in the genetic material, and various types of chromosomal DNA alteration in plants such as deletion, substitution, point mutation, and inversion could be occurred (Shu et al., 2011). Genetic diversity is the basis for selection in order to obtain superior alleles in rice mutant plants with disease-resistant properties (Ishak, 2012). Various M2 plants of mutant lines have been observed in the field and genetically analyzed for the bacterial leaf blight resistance gene $\mathrm{Xa} 5$ on the each dose of mutation induction is in Table 2.

The result displayed the only the numbers of mutant lines with positive and some of negative bands of Xa gene. Xa5 is an important race-specific recessive gene in rice breeding due to its broad resistance spectrum to most Xoo strains.The results were shown that all mutant lines carry resistance alleles for $\mathrm{Xa} 5$ by the doses of $25 \mathrm{~Gy}, 150 \mathrm{~Gy}$ and $200 \mathrm{~Gy}$, equal to parent plant pattern and Code variety of the

Table 2. Pattern amplification of rice mutant lines by using Xa5 gene

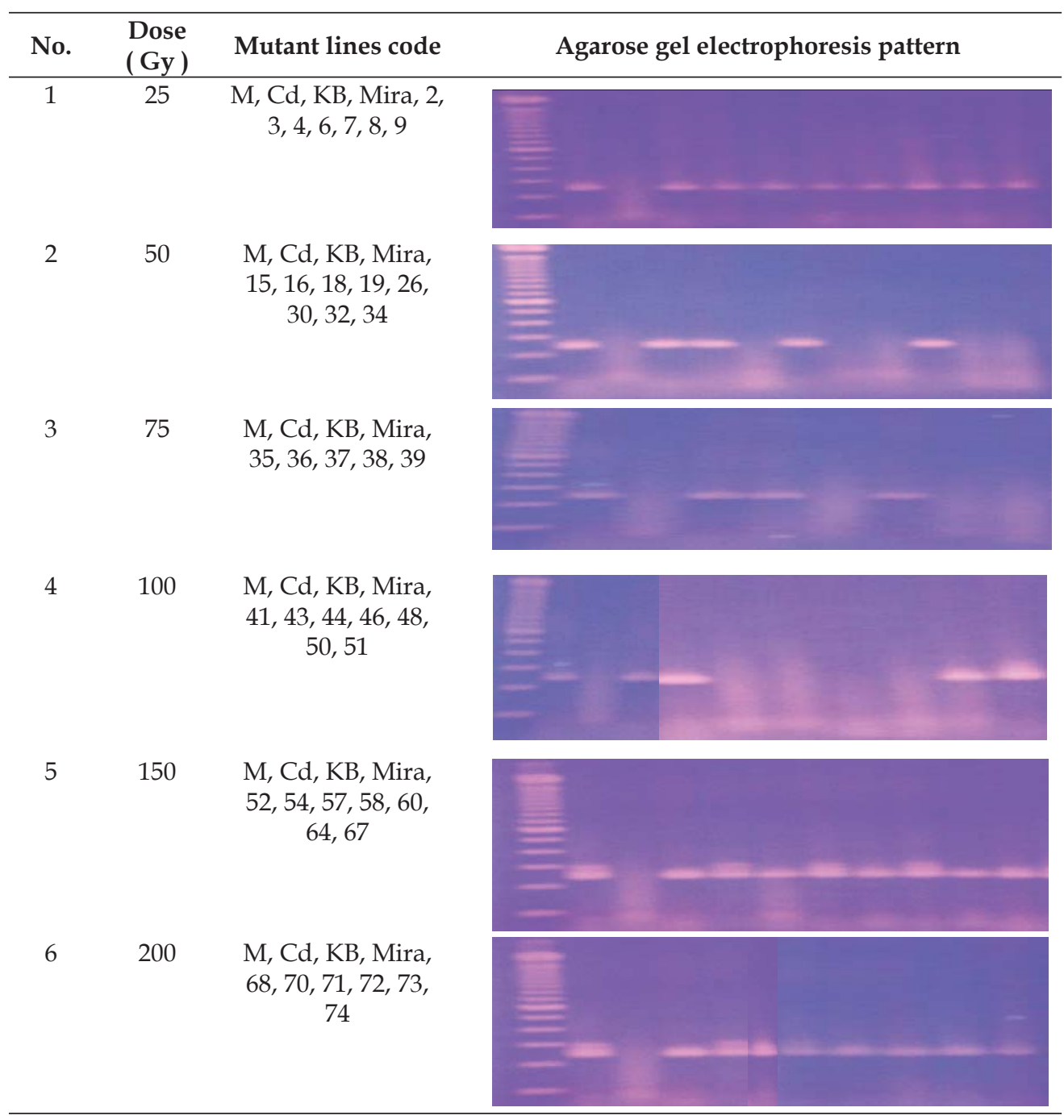


positive control. Mira-1 has known contains $\mathrm{Xa} 5$ and must be maintained in the rice mutant lines. However, by the doses of $50 \mathrm{~Gy}$ and 100 Gy, only 2 mutant lines carry resistance alleles of $\mathrm{Xa5}$ respectively, and by the dose of 75 Gy were smear band appeared even though analysis was done three times. In comparing Mira-1 as their parent plant, it is shown that mutation by the dose of 100 Gy affected on more disappearing of Xa5 containing in mutant lines than other doses. From thirty four lines, twenty lines of them along with resistant checks amplified $219 \mathrm{bp}$ size fragments indicating the presence of xa5 (Singh et al., 2015).

The Xa5 is a novel disease $\mathrm{R}$ gene, provides immunity to races of Xhantomonas oryzae pv.oryzae. The positional cloning identifies of this gene in an $8.1 \mathrm{~kb}$ region region of TFIIAY in the subtelomeric region of chromosome 5, which probably confer resistance by modulating activation of other TALE targets (Leung et al., 2015). FIIAY is very essential for cell growth and has been shown to have several roles in transcription, including stimulation and stabilization of the interaction between the TATA-box binding protein, promoter selection, genespecific regulation, and activator-dependent transcription.

The rice resistance against diseases is highly important target in plant breeding, therefore, mutation induction produce

Table 3. Pattern amplification of rice mutant lines by using Xa13 gene

\begin{tabular}{|c|c|c|c|}
\hline No. & Dose (Gy) & Mutant lines code & Agarose gel electrophoresis pattern \\
\hline 1 & 25 & $\begin{array}{l}\text { Marker, Code, Kencana Bali, } \\
\text { Mira-1, 2, 3, 4, 6, 7, 8, } 9\end{array}$ & E $\quad----$ \\
\hline 2 & 50 & $\begin{array}{c}\text { M, Cd, KB, Mira, 15, 16, 18, } \\
19,26,30,32,34\end{array}$ & E \\
\hline 3 & 75 & $\begin{array}{c}\text { M, Cd, KB, Mira, 35, } 3637 \\
38,39\end{array}$ & - \\
\hline 4 & 100 & $\begin{array}{c}\text { M, Cd, KB, Mira, 41, 43, 44, } \\
46,48,50,51\end{array}$ & 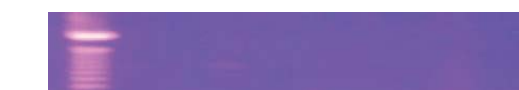 \\
\hline 5 & 150 & $\begin{array}{c}\text { M, Cd, KB, Mira, 52, 54, 57, } \\
58,60,64,67\end{array}$ & $=$ \\
\hline 6 & 200 & $\begin{array}{l}\text { M, Cd, KB, Mira, 68, 70, } \\
71,72,73,74\end{array}$ & 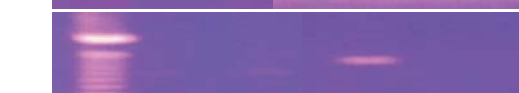 \\
\hline
\end{tabular}


mutant lines that have broad resistance trait is a challenge for plant breeders and pathologist. Rice mutant lines along with resistant check Code variety as positive control and Kencana Bali as negative control were analyzed for Xa13 gene and the result is displayed in Table 3. Screening for disease responses revealed that various alteration have occurred in the gamma rays - mutant lines. It shows that by the dose of $25 \mathrm{~Gy}$ very clear band occured for all mutant lines, and found that four mutant lines by the dose of 150 Gy contain Xa13. Code shows smear band as also displayed by Mira-1 as the parent plant. Mutation induction by the doses of 50 and 100 Gy apparently have none band, and this only one was also found in mutant line number 37 and 70 by the doses of 75 and 200 Gy respectively. Han et al. (2004) found that 3 lines from 26 lines of gamma rice mutants were identified blast resistant. It was occured $\mathrm{T}$ base-pair deletion and early stopped coding at 60 and $67 \mathrm{bp}$ after translation initiation region in $\mathrm{hd}(\mathrm{t})$ mutant compared to parent plant (Shang et al. 2012). Pradhan et al. (2015) mentioned that backrossing of Jalmagna rice was found $100 \mathrm{BC} 1 \mathrm{~F} 1$ plants showed presence $\mathrm{Xa5}$, and 91 of plants showed presence of $\mathrm{Xa13}$ and Xa21 from 360 BC1F1 seeds. The blight attack is characterized by changes in the appearance of plants, starting immediately

Table 4. Pattern amplification of rice mutant lines by using Xa21 gene

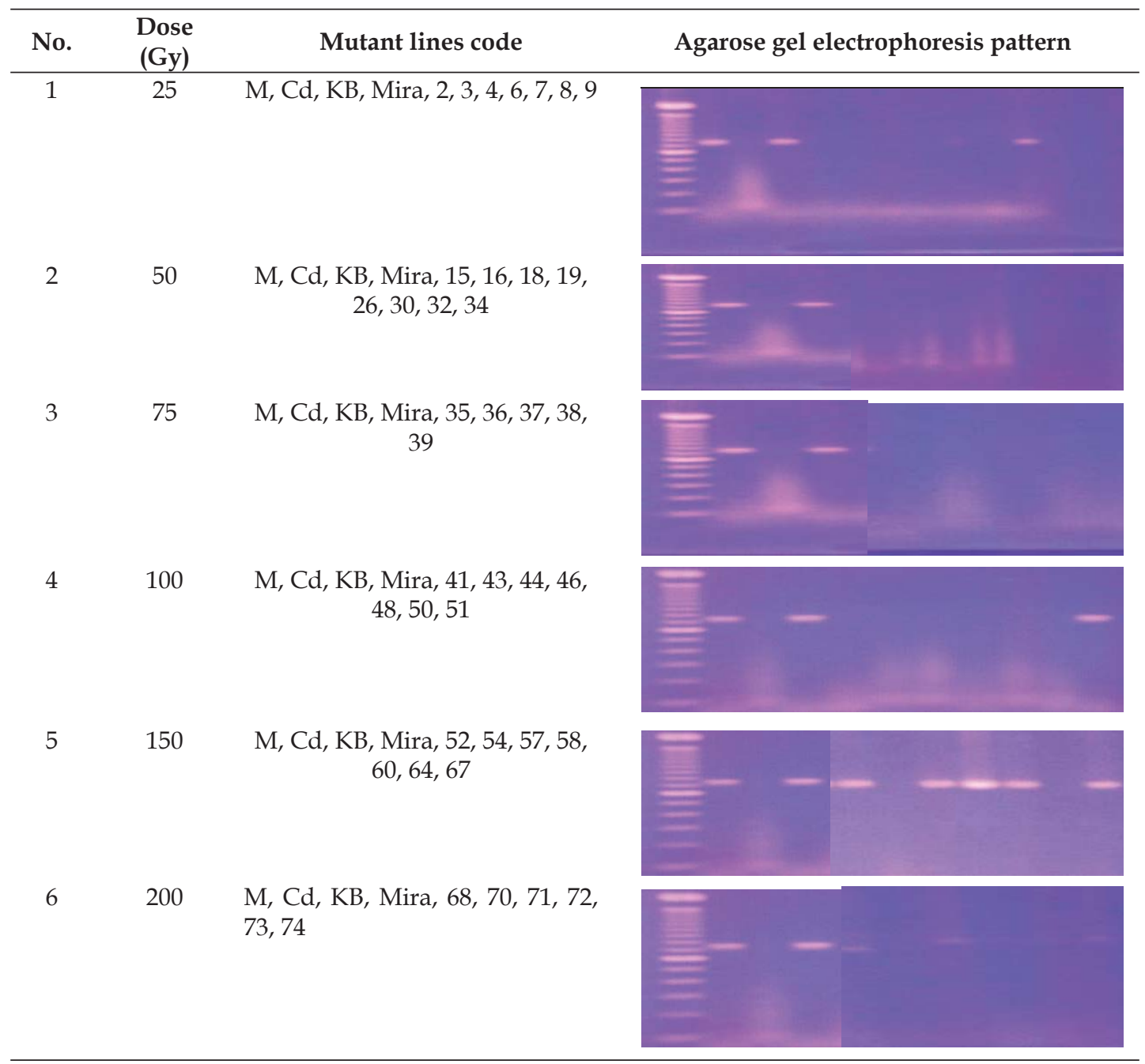


Aryanti et al.

with wilting in most tissues (especially the leaves), followed by chlorosis fast (in a few days), became brown and dead tissues on the surface could be seen.
I.J. Biotech.

BLB disease also causes the rice plants starting from seedling up to mature stage (Tasliah, 2012). Plants could defend themselves against pathogen because the plants have the

Table 5. Reaction of rice mutant lines toward Xanthomonas oryzae pv.Oryzae

\begin{tabular}{|c|c|c|c|c|c|}
\hline No. & Dose ( Gy ) & Line codes & $\mathrm{Xa5}$ & Xa13 & Xa21 \\
\hline 1 & & Code (control positive) & + & + & + \\
\hline \multirow[t]{2}{*}{2} & & Kencana Bali (Control negative) & - & - & - \\
\hline & & Mira-1 (parent plant) & + & - & + \\
\hline 3 & 25 & 2 & + & + & - \\
\hline 4 & & 3 & + & + & - \\
\hline 5 & & 4 & + & + & - \\
\hline 6 & & 6 & + & + & - \\
\hline 7 & & 7 & + & + & - \\
\hline 8 & & 8 & + & + & + \\
\hline 9 & & 9 & + & + & - \\
\hline 10 & 50 & 15 & + & - & - \\
\hline 11 & & 16 & - & - & - \\
\hline 12 & & 18 & + & - & - \\
\hline 13 & & 19 & - & - & - \\
\hline 14 & & 26 & - & - & - \\
\hline 15 & & 30 & + & - & - \\
\hline 16 & & 32 & - & - & - \\
\hline 17 & & 34 & - & - & - \\
\hline 18 & 75 & 35 & + & - & - \\
\hline 19 & & 36 & - & - & - \\
\hline 20 & & 37 & + & + & - \\
\hline 21 & & 38 & - & - & - \\
\hline 22 & & 39 & - & - & - \\
\hline 23 & 100 & 41 & + & - & - \\
\hline 24 & & 43 & - & - & - \\
\hline 25 & & 44 & - & - & - \\
\hline 26 & & 46 & - & - & - \\
\hline 27 & & 48 & - & - & - \\
\hline 28 & & 50 & + & - & - \\
\hline 29 & & 51 & + & - & + \\
\hline 30 & 150 & 52 & + & + & + \\
\hline 31 & & 54 & + & - & - \\
\hline 32 & & 57 & + & + & + \\
\hline 33 & & 58 & + & + & + \\
\hline 34 & & 60 & + & + & + \\
\hline 35 & & 64 & + & - & - \\
\hline 36 & & 67 & + & - & + \\
\hline 37 & 200 & 68 & + & - & \\
\hline 38 & & 70 & + & - & - \\
\hline 39 & & 71 & + & + & - \\
\hline 40 & & 72 & + & - & - \\
\hline 41 & & 73 & + & - & - \\
\hline 42 & & 74 & + & - & - \\
\hline
\end{tabular}


gene coding for disease-defense which is known as Xa genes. Detection of mutant lines containing of $X a$ genes is very helpful in the initial purification of rice mutant tolerant to BLB disease.

Rice mutant lines appearing with a band size of $750 \mathrm{bp}$ of Xa21, displayed in Table 4. Mutation induction by the dose of 150 Gy was the best dose to obtain the mutant lines containing Xa21 compared to other doses, only one mutant line with the same lines was found at the doses of $25 \mathrm{~Gy}$ and $100 \mathrm{~Gy}$, and none at the doses of 75 and 200 Gy respectively. Gamma rays could affected on loss-of-function and gain-offunction of rice mutants (Wu et al., 2005). The rice gene, $X a 21$, encodes a receptorlike kinase with leucine-rich repeats in the extra cellular domain (Swamy et al., 2006). Wang et al. (2004) reported that from 23 mutants from irradiated of IRBB21 with fastneutron 20Gy, 6 mutant lines found fully susceptible carried rearrangement at the $\mathrm{X} a 21$ as detected by PCR and southern blots, while 17 mutants with partial resistance had no visible deletions or rearrangements at the Xa21 locus. Wang et al. (2004) also mentioned the possibility that point mutation or small deletions could have occurred at Xa21 locus. According to Singh et al. (2015), during the polymorphic survey of thirty four rice cultivars, no amplicons specific to Xa21 and Xa13 allele were detected. Campbell and Ronald (2005) found that mutant line from irradiated rice by 15 Gy fast-neutron having enhanced resistance to only CA-1, may represent a mutation susceptible of factor for M. grisea. Furthermore, Yin et al. (2015) found that a deletion of $2446 \mathrm{bp}$ from the $9^{\text {th }}$ to the $14^{\text {th }}$ exon of Os08g19320 in the vsl mutant, and deletion occurred in the vegetative senescence of the lethal mutant.

Table 5 displayed the positive and negative response of rice mutant lines on three kinds of Xanthomonas resistance gene detection.

\section{Conclusion}

Marker assisted selection of rice mutant lines could help to identify the lines containing the $X a 5, X a 13$ and $X a 21$ which indicate them as tolerant to bacterial leaf blight (BLB) disease genetically. Mutation induction by the doses of 25 Gy and 150 Gy were better than other doses, it was found 5 rice mutant lines which were contains of Xa5, Xa13 and $\mathrm{Xa21}$ genes with band size like Code rice variety as the control positive.

\section{Acknowledgement}

Authors are thankful to Mr. Carkum and Mr. Munata for their agronomic observation in the field, financial supported by DIPA PAIR, BATAN is acknowledgement.

\section{References}

Baehaki. 2012. Pests brown plant hopper biotype development on Rice. Science and Technology CROPS. Vol 7 (1) : 8-17.

Campbell M.A., and Ronald P.C. 2005. Characterization of four rice mutants with alterations in the defense response pathway. Molecular Plant Pathology 6 (1) : 11-21.

Han C. H., Lee C. H, Jang K. S., Choi G. J., Lim H. K., Kim J. C., Ahu S. N., Choi J. E., Cha J. S., Kim H. T., Cho K. Y. and Lee S. W. 2004. Identification of rice genes induced in a rice blast-resistant mutant. Mol. Cells 17(3) : 462 - 468.

Herlina L., and Silitonga T.S. 2011. Field selection of several rice varieties for resistance to bacterial leaf blight strain IV and VIII. Bulletin Germplasm 17(2) : 80-87.

Ishak. 2012. Agronomic traits, heritability and $\mathrm{G} \times \mathrm{E}$ interaction of upload rice (Oryzae sativa L.) mutant lines. J. Agron. Indonesia 40(2): 105-11.

Leung H., Raghavan C, Zhou B, Oliva R, Choi R, Lacorte V, Jubay M.L, Cruz C.V, Gregorio G, Singh R.K, Ulat V.J, Borjaz F.N, Mauleon R, Alexandrof N.N, 
McNally K.L and Hamilton R.S. 2015. Allele mining and enhanced genetic recombination for rice breeding. Rice 8 (34) : 2 -11.

Lukman R., Afifuddin A and Hoerussalam. 2013. Technology utilization in molecular breeding crop of breeding resistance to mites and disease. Journal Agrotechnos 3(2) : $101-108$.

Pradhan S. K ., Nayak D. K, Mohanty S, Behera L, Barik S.R, Pandit E, Lenka S, and Anandan A. 2015. Pyramiding of three bacterial blight resistance genes for broad - spectrum resistance in deepwater rice variety, Jalmagna. Rice 8 (19) : 2-14.

Shang H., Ye S, Deng X, Zhou y, and Xiu F. 2012. Identiification and fine mapping of heading date related mutant gene in rice. Rice Science 19(4) : 299-278.

Shu, Q.Y., Foster B.P and Nakagawa H. 2011. Plant Mutation Breeding and Biotechnology. Joint FAO/IAEA, Vienna.

Singh A. K., P. K. Singh, Madhuri Arya, N. K. Singh and U.S. Singh. 2015. Molecular Screening of Blast Resistance Genes in Rice using SSR Markers. Plant Pathol. J. 31(1): 12-24.

Singh, A.K., Nayak R and Singh P.K. 2015. Identification of bacterial leaf blight resistance genes in rice (Oryzae sativa L.). International J. of Science and Nature. 6(2): 283- 287.

Suryadi, Y., Susilowati D.N, Kadir T.S, and Ruskandar A. 2012. Seed-dipping application of local endophytic bacterial consortium against bacterial leaf blight of rice. Agrotropica Journal 7 (11): 7-13 .

Swamy P., Panchbhai A.N, Dodiya P, Naik V, PanchbhaiS.D, Zehr U.B, Azhakanandam $\mathrm{K}$ and Char B.R. 2006. Evaluation of bacterial blight resistance in rice lines carrying multiple resistance genes and Xa21 transgenic lines. Curent Science 90(6) : 818 - 824.

Tanaka A., Shikazono N and Hase Y. 2010. Studies on biologcal effects of ion beam on lethality, molecular nature of mutation, mutation rate, and spectrum of mutation phenotype for mutation breeding in higher plants. J. Rad. Res. 51 : 223-233.

Tasliah. 2012. Resistance gene on rice to bacterial leaf blightcaused by Xhantomonas oryzae pv.oryzae. Journal of Agricultural R \& D, 31 (3) : 103 - 112.

Wang G. I., Wu C., Zeng L, He C., Baraodan M., Silva F.D. A., Williams C. E., Ronald P. C and Leung H. 2004. Isolation and caharcterization of rice mutants compromised in Xa21-mediated resistance to X.oryzae pv.oryzae. Theor. Appl. Genet. 108: 379-384.

Wu J., Wu C., Lei C., Baraoidan M., Bordeos A., madamba M.R.Sm Pamplona M. R., Mauleon R., Portugal A., Ulat V. J., Bruskiewich R., Wang G., Leach J., Kush G. and Leng H. 2005. Chemical-and irradiation-induced mutants of indica rice IR64 for forward and reverse genetics. Plant Molecular Biology 59 : 85-97.

Zhang, H., and Wang S. 2013. Rice versus Xhantomonas oryzae pv.oryzae: a unique pathosystem. Current Opinion in Plant Biology 16 : 188 - 195.

Yin J., Zhu X., Yuan C., Wang J., Li W., Wang Y., He M. H., Cheng Q., Ye B., Chen W., Linghu Q., Wang J., Ma B., Qin P., Li S. and Chen X. 2015. Characterization and fine mapping of a novel vegetative senescence lethal mutant locus in rice. Journal of Genetics and Genomics 42 : 511-514. 